\title{
Chemical and sensory properties of household and industrially produced Bosnian sudzuk
}

\begin{abstract}
Suzana Jahićl ${ }^{*}$, Sebila Rekanovićl
A b s t r a c t: Sudzuk, a Bosnian dry fermented sausage, is traditionally made from beef, beef tallow, table salt, garlic and pepper. In this paper, the chemical and sensory properties of household-and industrially-produced Bosnian sudzuk were investigated. The technological processes in both cases of preparation and production of sudzuk were carried out in a manner specific to the given product. Chemical analyses (moisture, total ash, sodium chloride, total acids, fat, protein and $p H$ ) showed the different sudzuk produced by three households had some statistically significantly $(p<0.05)$ different parameters. Among the industrially produced sudzuk (from four different companies) the moisture content, total ash, sodium chloride, total acids, protein and $p H$ were different ( $p<0.05)$, while the fat content did not significantly differ between the producers $(p>0.05)$. Instrumental colour measurement indicated statistically significant differences $(p<0.05)$ for $a^{*}$ between the sudzuk produced in the households, for a* between those produced in industrial conditions, and for $L^{*}$ between the industrially produced sudzuk. No statistically significant difference ( $\left.p>0.05\right)$ was determined for $b^{*}$ between the sudzuk produced in households or between those produced in industrial conditions. In sensory evaluation, differences $(p<0.05)$ were found in the overall grades of the sudzuk produced by households, while the overall grades of the industrially produced sudzuk did not statistically differ ( $p>0.05$ ).
\end{abstract}

Keywords: Bosnian sudzuk, traditional and industrial production, chemical and sensory properties.

\section{Introduction}

Sudzuk is a dry fermented sausage, very popular in Turkey and in Middle East countries, as well as in Europe (Ercoskun and Özkal, 2011). In Bosnia and Herzegovina, it is traditionally produced in small plants or village households in autumn and winter when weather conditions (temperature and relative humidity) are favourable.

According to Bosnian law (Official Gazette $B i H, 2013)$, sudzuk is a shelf-stable sausage that is produced according to the manufacturer's specification. Earlier, it was produced only in households and artisanal slaughterhouses, while in the last few decades, sudzuk has been made by meat companies for the urban population.

Sudzuk is produced from a mixture of meat and fat; the mixture includes beef, sheep and/or buffalo meat, beef tallow and sheep tallow with the addition of salt, sugar, garlic, pepper and some other spices. After mixing, the stuffing is filled into a casing and the sausage is subjected to fermentation under specified conditions to produce the final result: a semi dry or dried meat product
(Özgal and Ercoksun, 2016). According to Toldra and Reig (2011), sudzuk produced by natural fermentation are nutritionally valuable due to their high quality protein, B group vitamins, mineral elements, trace elements and some bioactive compounds. Erkmen and Bozkurt (2004) concluded that lipid oxidation in sudzuk could have significant influence on the qualities of colour, flavour, texture and nutritional value. Operta et al. (2007) state that frozen beef of III category was used in industrial conditions for the production of sudzuk, and Čengić et al. (2008) used beef meat of I and II categories.

Previous research and determination of physical-chemical and sensory properties based on moisture content, fat, protein, $\mathrm{NaCl}$, ash, $\mathrm{pH}$, water activity $\left(\mathrm{a}_{\mathrm{w}}\right)$, and the sensory properties showed sudzuk can have rather variable values (Operta et al., 2012). Therefore, in this study, the most important physico-chemical parameters and the most important sensory properties were investigated in Bosnian sudzuk produced traditionally and in industrial conditions from fresh, chilled and frozen beef of II and III category. 


\section{Materials and Methods}

Sudzuk were produced in households or in industrial conditions, according to the producer's specification. For the needs of chemical and sensory analyses, several sudzuk were taken from four different household producers and at retail from three different industrial producers in the Una-Sana Canton. Sudzuk were coded and harmonized for further research needs in the winter of 2020, and three samples (horseshoes) were taken from each producer. Producers were: A1, domestic producer 1; A2, domestic producer 2; A3, domestic producer 3; A4, domestic producer 4 ; $\mathrm{B} 1$, industrial producer 1 ; $\mathrm{B} 2$, industrial producer 2 and; B3, industrial producer 3 . Samples of household-produced sudzuk were taken in a bulk package, and samples of industrially produced sudzuk were taken packed in a polyamide-polyethylene bags and vacuumed. Chemical and sensory analyses were performed in the Laboratory for Control and Quality of the Biotechnical Faculty.

Selected frozen beef from suppliers, beef tallow, $55 \mathrm{~mm}$ diameter collagen, black pepper, fresh garlic and nitrite salt were used for the production of Bosnian sudzuk in industrial conditions. The meat was partially cut to a $5 \mathrm{~cm}$ thickness and $30 \mathrm{~cm}$ width, and chopped to a granulation of $5 \mathrm{~mm}$. The meat was further minced in a cutter together with the spice mixture and nitrite salt. After cutting, the filling was transferred to a vacuum filler where it was filled into collagen wrappers and closed by clipping. The formed horseshoe shaped sausages were hung on poles on a cart and left to drain for $12 \mathrm{~h}$. The drained sudzuk was transported to a conditioned chamber for ripening, drying and smoking in controlled temperature and humidity conditions. The process lasted for 20 days (depending on the piece and the position in the chamber), until the desired sensory properties of the product were achieved. The initial ripening temperature in the chamber was from $14^{\circ} \mathrm{C}$ to $15^{\circ} \mathrm{C}$, and the relative humidity was maintained at about $72 \%$. After ripening and drying, the sudzuk were packed in polyamide-polyethylene bags, vacuumed and stored in a warehouse (temperature range from 4 to $5^{\circ} \mathrm{C}$, maximum up to $15^{\circ} \mathrm{C}$ ).

For household sudzuk, the following ingredients were used: beef meat, beef tallow, table salt, black pepper and garlic. Meat and beef tallow were chopped manually with a knife into small pieces with addition of table salt, black pepper and garlic. After mixing meat and tallow together with spices, the mixture was left to ripen for 5 days in a cold place (about $5^{\circ} \mathrm{C}$ ). In the next step, the ripened mixture was ground in a meat grinder. After grinding, the filling was stuffed into thin beef casings. Before use, casings were salted and left in warm water to become elastic. A sausage stuffer was used to stuff the filling into the casings, which were stuffed well, in order to become firm. After stuffing, the sudzuk were tied up into ring shapes and placed on a pole without touching each other. Then, sudzuk were stored in a room with average temperature about $10^{\circ} \mathrm{C}$ for one day, and then, the sausages were arranged on rounded poles to be equally smoked and dried. The sausages were smoked and dried in a typical smokehouse with an open furnace for 10 days without the possibility to control the temperature or humidity. Beech wood was used to create flameless smoke. After smoking, sudzuk were left to ripen 5 days in a room with average temperature of $10^{\circ} \mathrm{C}$.

\section{Chemical analysis}

Water content (drying at $105^{\circ} \mathrm{C}$ to constant mass) was determined according to BAS ISO 1442 (ISO, 2007a), fat content (according to the Soxhlet method) using BAS ISO 1443 (ISO, 2007d), and protein content (according to the Kjeldahl method) using BAS ISO 937 (ISO, 2007b). Determination of total ash/mineral matter in sausages was by the method of dry incineration BAS ISO 936 (ISO, 2007c) and the content of sodium chloride was determined according to the Mohr method (ISO, 1996). The content of organic acids expressed as malic acid and was determined according to Trajković et al. (1983).

\section{pH measurement}

The $\mathrm{pH}$ was determined according to the reference method (ISO, 2004). Measurements were made using a digital pH meter (TESTO 206, Germany). Before and during reading the $\mathrm{pH}$, the $\mathrm{pH}$ meter was calibrated using standard buffer solution ( $\mathrm{pH}$ buffer calibration was 7.00 and 4.01 at $20^{\circ} \mathrm{C}$ ). The result is expressed as the arithmetic mean of eight measurements.

\section{Instrumental colour measurement}

Instrumental colour measurement was performed using a colorimeter LCC-A11 (LABTRON, United Kingdom), with $8 \mathrm{~mm}$ port size, illuminant D65 and a $10^{\circ}$ standard observer, and after standardization of the instrument with respect to the white calibration plate. Colour parameters, expressed as CIE L*, $a^{*}$ and $b^{*}$ values, were determined as indicators of lightness, redness and yellowness. For the 
colour determination, measurement was done immediately after cutting the sudzuk to prevent colour degradation, which can occur as a result of light and oxygen. The mean of five measurements was recorded for each colour parameter.

\section{Descriptive sensory analysis}

Descriptive sensory analysis was used to evaluate sudzuk quality. The panel consisted of a group of five trained evaluators, and the overall sensory quality of Bosnian sudzuk was assessed by the quantitative descriptive analysis method (ISO, 1985) in order to identify the relative quality of selected product properties. In the sensory evaluation, the coefficient of significance (Cs) was determined for each selected sensory attribute/parameter (there were 20 of these). Appropriate Cs were multiplied by the sensory evaluation score for each selected attribute.
The most important sensory attributes were evaluated: outside appearance and/or casing $(\mathrm{Cs}=2)$, cut appearance $(\mathrm{Cs}=5)$, cut colour $(\mathrm{Cs}=3)$, smell, aroma and flavour $(\mathrm{Cs}=7)$; consistency $(\mathrm{Cs}=3)$.

\section{Statistical analysis}

The results of this study are presented as the mean values accompanied by standard deviations. One factor analysis of variance (ANOVA) was performed using statistical software SPSS (VER.20). When the main impact was significant, averages were split by Tukey's test of the smallest significant deviations at $5 \%$ level.

\section{Results and Discussion}

Tables 1 and 2 show the results of chemical analyses of the Bosnian sudzuk.

Table 1. The average chemical composition and $\mathrm{pH}$ of Bosnian sudzuk produced in households $(\mathrm{n}=12)$

\begin{tabular}{lcccc}
\hline \multirow{2}{*}{ Parameters (\%) } & \multicolumn{4}{c}{ Producers } \\
\cline { 2 - 5 } & $\mathbf{A 1}$ & $\mathbf{A 2}$ & $\mathbf{A 3}$ & $\mathbf{A 4}$ \\
\hline Water content & $26.02 \pm 4.35^{\mathrm{d}}$ & $37.77 \pm 3.57^{\mathrm{ab}}$ & $41.35 \pm 2.88^{\mathrm{ac}}$ & $41.46 \pm 4.04^{\mathrm{bc}}$ \\
Total ash & $4.54 \pm 0.34^{\mathrm{c}}$ & $6.82 \pm 0.40^{\mathrm{a}}$ & $6.44 \pm 0.32^{\mathrm{ab}}$ & $5.93 \pm 0.48^{\mathrm{b}}$ \\
$\mathrm{NaCl}$ & $4.20 \pm 0.05^{\mathrm{c}}$ & $6.74 \pm 0.07^{\mathrm{ab}}$ & $6.39 \pm 0.31^{\mathrm{a}}$ & $6.29 \pm 0.34^{\mathrm{b}}$ \\
Total acids & $0.06 \pm 0.01^{\mathrm{a}}$ & $0.08 \pm 0.02^{\mathrm{ab}}$ & $0.13 \pm 0.03^{\mathrm{c}}$ & $0.09 \pm 0.01^{\mathrm{ab}}$ \\
Protein & $24.77 \pm 0.71^{\mathrm{c}}$ & $28.99 \pm 0.70^{\mathrm{b}}$ & $33.35 \pm 1.17^{\mathrm{a}}$ & $32.03 \pm 1.36^{\mathrm{a}}$ \\
Fat & $47.96 \pm 2.64^{\mathrm{c}}$ & $33.04 \pm 1.84^{\mathrm{b}}$ & $23.52 \pm 1.31^{\mathrm{a}}$ & $20.80 \pm 3.65^{\mathrm{a}}$ \\
$\mathrm{pH}$ & $6.28 \pm 0.05^{\mathrm{a}}$ & $6.17 \pm 0.03^{\mathrm{b}}$ & $5.75 \pm 0.03^{\mathrm{c}}$ & $5.51 \pm 0.02^{\mathrm{d}}$ \\
\hline
\end{tabular}

Legend: Data are expressed as mean \pm standard deviation. Means with the same letter in the same row do not differ statistically at $5 \%$ $(\mathrm{p}>0.05) . \mathrm{A} 1=$ household producer $1, \mathrm{~A} 2=$ household producer $2, \mathrm{~A} 3=$ household producer $3, \mathrm{~A} 4=$ household producer 4.

Table 2. The average chemical composition and $\mathrm{pH}$ of Bosnian sudzuk produced in industrial conditions ( $\mathrm{n}=9$ )

\begin{tabular}{lccc}
\hline \multirow{2}{*}{ Parameters $(\%)$} & \multicolumn{3}{c}{ Producers } \\
\cline { 2 - 4 } & $\mathbf{B} 1$ & $\mathbf{B 2}$ & $\mathbf{B 3}$ \\
\hline Water content & $28.63 \pm 4.39^{\mathrm{a}}$ & $28.29 \pm 2.48^{\mathrm{a}}$ & $34.55 \pm 2.26^{\mathrm{b}}$ \\
Total ash & $5.87 \pm 0.62^{\mathrm{b}}$ & $4.43 \pm 0.28^{\mathrm{a}}$ & $5.13 \pm 0.32^{\mathrm{a}}$ \\
$\mathrm{NaCl}$ & $4.72 \pm 0.05^{\mathrm{a}}$ & $4.17 \pm 0.12^{\mathrm{b}}$ & $4.34 \pm 0.11^{\mathrm{c}}$ \\
Total acids & $0.06 \pm 0.02^{\mathrm{ab}}$ & $0.04 \pm 0.01^{\mathrm{a}}$ & $0.06 \pm 0.01^{\mathrm{b}}$ \\
Protein & $25.19 \pm 0.65^{\mathrm{a}}$ & $22.28 \pm 3.96^{\mathrm{b}}$ & $24.73 \pm 0.64^{\mathrm{a}}$ \\
Fat & $41.29 \pm 3.54^{\mathrm{a}}$ & $46.77 \pm 3.34^{\mathrm{a}}$ & $37.25 \pm 9.62^{\mathrm{a}}$ \\
$\mathrm{pH}$ & $5.50 \pm 0.01^{\mathrm{b}}$ & $5.81 \pm 0.04^{\mathrm{a}}$ & $5.77 \pm 0.08^{\mathrm{a}}$ \\
\hline
\end{tabular}

Legend: Data are expressed as mean \pm standard deviation. Means with the same letter in the same row do not differ statistically at $5 \%$ $(\mathrm{p}>0.05) . \mathrm{B} 1=$ industrial producer $1, \mathrm{~B} 2=$ industrial producer $2, \mathrm{~B} 3=$ industrial producer 3. 
For the Bosnian sudzuk produced in households, the lowest moisture content was found in that from producer A1 (26.02\%), and the highest moisture content was found in that from producer A4 (41.46\%). Jahić and Pračić (2018) determined an average moisture content of $43.58 \%$ for samples of domestic Bosnian sudzuk with beef, and Ganic et al. (2018) determined the moisture content of high beef sudzuk to be $35.01 \%$. For the Bosnian sudzuk produced in industrial conditions, the moisture content ranged from $28.29 \%$ in sausage from producer B2 to $34.55 \%$ in sausage from producer B3. Siriken et al. (2009), for Turkish sudzuk, reported moisture content ranging from $29.80 \%$ to $47.60 \%$. Operta et al. (2012) recorded the moisture content in sudzuk made from chilled meat as $32.87 \%$, and in sudzuk made from frozen meat as $30.11 \%$. Kurćubić et al. (2016) recorded the moisture content was $19.44 \%$ in industrially-produced sudzuk, and $38.74 \%$ in domestically-produced sudzuk. According to $O p$ erta (2018), the average moisture content in Bosnian sudzuk produced in a ripening chamber ranged from $31.40 \%$ to $34.17 \%$. Due to drying in uncontrolled conditions in domestic production, the finished sudzuk product remains as "raw" (Kurćubić et al., 2016). According to Dučić et al. (2018), the higher moisture content in one sample of industrial sudzuk was due to the use of chilled meat. According to Bosnian legislation (Official Gazette BiH, 2013), fermented dry sausages after drying and ripening contain a maximum $40 \%$ of moisture.

The ash content in the Bosnian sudzuk produced in households ranged from $4.54 \%$ A1 to 6.82 A2. Jahić and Pračić (2018) determined an ash content of $6.85 \%$ for the samples of domestic sudzuk made from beef, and Ganić et al. (2018) determined an ash content of $6.29 \%$ for Visoko sudzuk (this is from Visoko, $\mathrm{BiH}$ ). In this study, the ash content in the Bosnian sudzuk produced in industrial conditions ranged from $4.43 \% \mathrm{~B} 2$ to $5.87 \mathrm{~B} 1$. The content of mineral substances in sudzuk produced in industrial conditions was earlier determined to be $5.16 \%$ (Kurćubić et al., 2016), 5.85\% in cooled meat sausages (Operta et al., 2012), and 5.56\% in frozen meat sausages. According to Dučić et al. (2018), the ash content was in the range from $4.70 \%$ to $5.50 \%$ on the $15^{\text {th }}$ day of sudzuk production by three different industrial producers.

The lowest $\mathrm{NaCl}$ content in the samples of Bosnian sudzuk produced in households was $4.20 \%$ in the sausage from producer $\mathrm{A} 1$, and the highest $\mathrm{NaCl}$ content was $6.74 \%$ in sausage from producer A2. Ganić et al. (2018) also recorded a relatively high
$\mathrm{NaCl}$ content in Visoko domestic sudzuk (5.27\%), and Jahić and Pračić (2018) recorded a $\mathrm{NaCl}$ content of $3.00 \%$ in domestic beef sudzuk. Kurćubić et al. (2016) found a slightly lower $\mathrm{NaCl}$ content for sudzuk produced in industrial conditions compared to sudzuk produced in households $(4.70 \%$ and $5.12 \%$, respectively). In this study, the $\mathrm{NaCl}$ content in industrial sudzuk ranged from $4.17 \% \mathrm{~B} 2$ to $4.72 \%$ B1. Operta et al. (2012) reported the $\mathrm{NaCl}$ content in industrial sudzuk: $4.74 \%$ for sudzuk made from chilled meat, and $4.41 \%$ for sudzuk made from frozen meat, levels in accordance with the results of this study. Dučic et al. (2018) recorded the $\mathrm{NaCl}$ contents in industrially produced sudzuk ranged from $3.60 \%$ to $4.10 \%$ on the $15^{\text {th }}$ day of production.

The lowest content of total acids (expressed as malic acid) in Bosnian sudzuk produced in households was found in sausage from producer A2 $(0.08 \%)$, and the highest in sausage from producer A3 $(0.13 \%)$. The lowest $\mathrm{pH}$ was recorded in sudzuk from producer $\mathrm{A} 3$ ( $\mathrm{pH}$ 5.75), and the highest in sudzuk from producer $\mathrm{A} 1$ ( $\mathrm{pH}$ 6.28). The content of total acids in sudzuk from producer A1 was $0.06 \%$. Kurćubić et al. (2016) recorded pH 5.02 in domestic sudzuk, and pH 4.80 in industrial sudzuk. Jahić and Pračić (2018), found dried domestic sudzuk were pH 5.44 and 5.72, and Ganić et al. (2018) recorded pH 5.21 for Visoko sudzuk. In this study, the following $\mathrm{pH}$ values were found in Bosnian sudzuk produced in industrial conditions: B1 5.50, B3 5.77 and $5.81 \mathrm{~B} 2$. Operta (2018) recorded the average $\mathrm{pH}$ of 5.10 (with variation from 4.8 to 5.2). According to Dučić et al. (2018), the lowest $\mathrm{pH}$ was found in sausages with higher amounts of glucono-delta-lactone, and the highest $\mathrm{pH}$ values were in sausages where glucono-delta-lactone was not added. The $\mathrm{pH}$ of factory and butcher's sudzuk varied from $\mathrm{pH} 4.53$ to 5.77, and pH 4.83 to 6.74, respectively (Erkmen and Bozkurt, 2004).

The protein contents in Bosnian sudzuk produced in households were: $24.77 \% \mathrm{~A} 1,28.99 \% \mathrm{~A} 2$, $32.03 \%$ A4 and $33.35 \%$ A3. Slightly lower protein contents were recorded in sudzuk produced in industrial conditions: $22.28 \%$ B2, $24.73 \%$ B3, $25.19 \%$ B1. According to Operta (2018), the average protein content in sudzuk was $32.42 \%$, and ranged from $30.20 \%$ to $35.15 \%$. Kurćubić et al. (2016) recorded protein contents in domestic sudzuk of $21.12 \%$ and in industrial sudzuk of $20.60 \%$.

In this study, the fat content of domestic sudzuk varied from $20.80 \%$ A4 to $47.96 \%$ A1. In industrial sudzuk, the fat content ranged from $37.25 \%$ B3 to $46.77 \%$ B2. Kurćubić et al. (2016) recorded a 
Table 3. Instrumental colour measurements on the surface of Bosnian sudzuk produced in households ( $\mathrm{n}=12$ )

\begin{tabular}{lcccc}
\hline \multirow{2}{*}{ Parameters $(\mathbf{n}=\mathbf{5})$} & \multicolumn{4}{c}{ Producers } \\
\cline { 2 - 5 } & $\mathbf{A 1}$ & $\mathbf{A 2}$ & $\mathbf{A 3}$ & $\mathbf{A 4}$ \\
\hline $\mathrm{L}^{*}$ & $48.82 \pm 5.75^{\mathrm{a}}$ & $45.24 \pm 7.68^{\mathrm{a}}$ & $41.39 \pm 5.67^{\mathrm{a}}$ & $43.32 \pm 8.49^{\mathrm{a}}$ \\
$\mathrm{a}^{*}$ & $1.32 \pm 1.72 \mathrm{~d}$ & $10.61 \pm 3.74^{\mathrm{ab}}$ & $8.01 \pm 1.40 \mathrm{a}^{\mathrm{c}}$ & $8.66 \pm 3.84 \mathrm{~b}^{\mathrm{c}}$ \\
$\mathrm{b}^{*}$ & $9.97 \pm 0.82^{\mathrm{a}}$ & $7.58 \pm 2.02^{\mathrm{a}}$ & $10.61 \pm 2.6^{\mathrm{a}}$ & $7.48 \pm 2.55^{\mathrm{a}}$ \\
\hline
\end{tabular}

Legend: Data are expressed as mean \pm standard deviation. Means with the same letter in the same row do not differ statistically at $5 \%$ ( $p>0.05$ ). A1 household producer 1, A2 household producer 2, A3 household producer 3, A4 household producer 4.

Table 4. Instrumental colour measurements on the surface of Bosnian sudzuk produced in industrial conditions $(n=9)$

\begin{tabular}{lccc}
\hline \multirow{2}{*}{ Parameters $(\mathbf{n}=\mathbf{5})$} & \multicolumn{3}{c}{ Producers } \\
\cline { 2 - 4 } & B1 & B2 & B3 \\
\hline L* $^{*}$ & $39.35 \pm 2.93^{\mathrm{a}}$ & $47.21 \pm 3.09^{\mathrm{b}}$ & $42.91 \pm 4.27^{\mathrm{ab}}$ \\
$\mathrm{a}^{*}$ & $15.54 \pm 1.04 \mathrm{~b}$ & $8.00 \pm 1.92 \mathrm{a}$ & $10.84 \pm 3.67^{\mathrm{a}}$ \\
$\mathrm{b}^{*}$ & $10.28 \pm 2.5^{4 \mathrm{a}}$ & $11.12 \pm 1.4^{8 \mathrm{a}}$ & $8.14 \pm 1.94^{\mathrm{a}}$ \\
\hline
\end{tabular}

Legend: Data are expressed as mean \pm standard deviation. Means with the same letter in the same row do not differ statistically at $5 \%$ ( $\mathrm{p}>0.05)$. B1 Industrial producer 1, B2 Industrial producer 2, B3-Industrial producer 3.

high fat content in industrial sudzuk (47.05\%), and in domestic sudzuk (27.98\%). Operta (2018) obtained an average fat content in sudzuk of $28.46 \%$, ranging from $24.0 \%$ to $32.41 \%$.

Values of the colour parameters L* (lightness), $a^{*}$ (redness) and $b^{*}$ (yellowness) on the surface of sudzuk produced in households are shown in Table 3 , and those for sudzuk produced in industrial conditions are in Table 4 . No statistically significant difference $(p>0.05)$ was found for $L^{*}$ for the Bosnian sudzuk produced in the four households, while for the Bosnian sudzuk produced in industrial conditions, we found statistically significant differences $(p<0.05)$ in $\mathrm{L}^{*}$ between producers $\mathrm{B} 1$ and $\mathrm{B} 2$. Values of $\mathrm{a}^{*}$ were statistically significantly different $(p$ $<0.05$ ) for the Bosnian sudzuk produced by the four households, and also for the sudzuk produced in industrial conditions. Redness a* is often use as an indicator of meat products' colour stability (Hromiš et al., 2013). No statistically significant differences $(p$ $>0.05$ ) were found for $b^{*}$ between the sudzuk produced in the four households or between those produced in industrial conditions. According to Bozkurt and Bayram (2006), the formation of colour in industrial sudzuk is due to the reduction of nitrate to nitrites by bacteria, while red pepper and sugar also contribute to the desired colouring of sudzuk.
Tables 5 and 6 show the results of sensory assessment of the Bosnian sudzuk.

The overall grades of sausages made in the households were significantly different $(p$ $<0.05$ ), while those of sausages produced in industrial conditions were not statistically significantly different $(p>0.05)$ between producers. The sudzuk from producer A1 had a fatty taste during chewing in the mouth, while saltiness was satisfactory, and the products had characteristic flavour and aroma. These sudzuk had the lowest table salt content of all the sausages evaluated. The sudzuk from producer A 2 was found to have a uniform colour and mosaic sections, a stronger flavour of smoke than other products, gently pronounced acidity and a pronounced saltiness. The stuffing was filled firmly and evenly in the casings. According to the results of chemical analysis, these sudzuk had the highest $\mathrm{NaCl}$ content. In the sudzuk from producer A3, the cross-sectional colour was lighter and with darker edges than the other household products. Toughness was felt during chewing, so the evaluators concluded these products were 
Table 5. The results of sensory assessment of Bosnian sudzuk produced in households $(n=12)$

\begin{tabular}{lcccc}
\hline \multirow{2}{*}{ Sensory properties } & \multicolumn{4}{c}{ Producers } \\
\cline { 2 - 5 } & $\mathbf{A 1}$ & $\mathbf{A 2}$ & $\mathbf{A 3}$ & $\mathbf{A 4}$ \\
\hline Outside appearance & $9.08 \pm 0.23 \mathrm{a}^{\mathrm{b}}$ & $8.12 \pm 0.42 \mathrm{~d}$ & $9.44 \pm 0.26 \mathrm{a}^{\mathrm{c}}$ & $9.56 \pm 0.09 \mathrm{~b}^{\mathrm{c}}$ \\
Cut appearance & $19.4 \pm 0.22^{\mathrm{a}}$ & $22.90 \pm 0.8^{9 \mathrm{~b}}$ & $17.50 \pm 1.9^{7 \mathrm{a}}$ & $23.20 \pm 0.5^{7 \mathrm{~b}}$ \\
Cut colour & $10.14 \pm 0.3^{9 \mathrm{a}}$ & $13.8 \pm 0.56^{\mathrm{b}}$ & $10.26 \pm 0.9^{3 \mathrm{a}}$ & $14.04 \pm 0.3^{3 \mathrm{~b}}$ \\
Smell, aroma and & $32.48 \pm 1.06^{\mathrm{b}}$ & $22.72 \pm 1.37^{\mathrm{a}}$ & $22.54 \pm 0.31^{\mathrm{c}}$ & $26.88 \pm 2.30^{\mathrm{a}}$ \\
flavour & $13.20 \pm 1.70^{\mathrm{ab}}$ & $12.36 \pm 0.78^{\mathrm{ac}}$ & $10.02 \pm 0.27^{\mathrm{c}}$ & $12.12 \pm 0.59^{\mathrm{b}}$ \\
Consistency & $84.30 \pm 1.2^{7 \mathrm{a}}$ & $84.90 \pm 1.1^{9 \mathrm{ab}}$ & $69.76 \pm 2.9^{0 \mathrm{c}}$ & $85.80 \pm 3.1^{1 \mathrm{cb}}$ \\
\hline
\end{tabular}

Legend: Data are expressed as mean \pm standard deviation. Means with the same letter in the same row do not differ statistically at $5 \%$ ( $>0.05$ ). A1 household producer 1, A2 household producer 2, A3 household producer 3, A4 household producer 4.

Table 6. The results of sensory assessment of Bosnian sudzuk produced in industrial conditions $(n=9)$

\begin{tabular}{lccc}
\hline \multirow{2}{*}{ Sensory properties } & \multicolumn{3}{c}{ Producers } \\
\cline { 2 - 4 } & B1 & B2 & B3 \\
\hline Outside appearance & $8.36 \pm 0.39 \mathrm{a}$ & $9.16 \pm 0.17 \mathrm{~b}$ & $8.56 \pm 0.43 \mathrm{a}$ \\
Cut appearance & $21.10 \pm 1.5^{6 \mathrm{ab}}$ & $23.40 \pm 0.6^{5 \mathrm{a}}$ & $20.20 \pm 1.7^{2 \mathrm{~b}}$ \\
Cut colour & $12.96 \pm 0.4^{\mathrm{ab}}$ & $13.74 \pm 0.2^{5 \mathrm{a}}$ & $12.00 \pm 1.2^{2 \mathrm{~b}}$ \\
Smell, aroma and flavour & $31.08 \pm 0.38^{\mathrm{a}}$ & $29.12 \pm 0.63^{\mathrm{ab}}$ & $28.84 \pm 2.07^{\mathrm{b}}$ \\
Consistency & $13.26 \pm 0.39^{\mathrm{a}}$ & $12.60 \pm 0.30^{\mathrm{a}}$ & $12.12 \pm 1.15^{\mathrm{a}}$ \\
Overall grade & $86.76 \pm 2.5^{5 \mathrm{a}}$ & $88.02 \pm 1.2^{2 \mathrm{a}}$ & $81.72 \pm 6.2^{9 \mathrm{a}}$ \\
\hline
\end{tabular}

Legend: Data are expressed as mean \pm standard deviation. Means with the same letter in the same row do not differ statistically at $5 \%$ $(\mathrm{p}>0.05)$. B1 Industrial producer 1, B2 Industrial producer 2, B3-Industrial producer 3.

not sufficiently dried. The evaluators agreed that the taste of pepper was more pronounced in these samples than in the other household sudzuk, with a slight note of smoke that resulted in a sour taste, while the consistency of the sudzuk was quite hard. Also, for these household sudzuk, differences in cross-sectional mosaicism were found. According to the results of Jahic and Pračić (2018), homemade Bosnian beef sudzuk had a pronounced, dark cross-section, with a pronounced mosaic and visible pieces of beef tallow, without cracks in the interior and with good consistency and satisfactory taste.

Sudzuk from producer B2, in comparison to the other industrial products, had a uniform surface appearance and a uniform mosaic in cross-section, with a lighter cross-sectional colour, more pronounced fat content and pronounced aromaticity due to the presence of a larger amount of spices. According to the evaluators, the sudzuk from producer B3 had a visible amount of adipose tissue of higher granulation and more pronounced fat content compared to the other assessed sausages. During chewing, greater toughness was felt, and the aromaticity of these sudzuk was more pronounced due to the presence of a large amount of black pepper. According to Operta et al. (2012), similar sensory properties were found for sudzuk made from chilled and frozen meat. However, sudzuk made from frozen (rather than chilled) meat had a better connection between muscle 
and fat tissue, a characteristic white colour of fat tissue and a more pronounced presence of bark. Both types of sudzuk were moderately fatty, with noticeable discrete acidity and a moderate garlic aroma. According to Kurćubić et al. (2016), sudzuk produced in households ranked better for external appearance and surface colour than those produced in industrial conditions. When evaluating product consistency, sudzuk obtained in industrial conditions was evaluated as better, but when evaluating the cross-section colour, smell and taste, no statistically significant differences were found between sudzuk produced in household and industrial conditions (Kurćubić et al., 2016). Two samples of sudzuk from producer B1 were found to have uneven surface colour, with significant separation of adipose tissue during cutting the sausage and softer consistency. The smell and taste of sudzuk from producer B1 were characteristic and satisfactory.

\section{Conclusion}

Based on the results obtained in this study, it can be concluded that the chemical properties of sudzuk produced domestically and industrially were not uniform, and variations existed in the moisture, protein, sodium chloride and fat contents. The $\mathrm{pH}$ of Bosnian sudzuk from different producers also differs. The sensory properties of the Bosnian sudzuk are quite uneven in terms of consistency, while deviations exist in terms of aroma and smell of the products. The largest differences in sensory properties were recorded for external appearance, cross-sectional appearance, and cross-sectional colour. These results are probably due to differences in sudzuk recipes, the origin of the raw materials, and the different approaches in the technological process of production. Therefore, the results of chemical and sensory analyses in this study should be used to help achieve uniform product quality, which in the future could result in Bosnian sudzuk being legally designated as of protected geographical origin or as a traditional specialty.

\title{
Hemijske i senzorne osobine domaćeg i industrijski proizvedenog bosanskog sudžuka
}

\author{
Suzana Jahić, Sebila Rekanović
}

A p s tr a k t: Sudžuk, bosanska suva fermentisana kobasica tradicionalno se proizvodi od goveđeg mesa, goveđeg loja, kuhinjske soli, belog luka i bibera. U ovom radu su istražene hemijske i senzorne osobine domaćeg i industrijski proizvedenog bosanskog sudžuka. U oba slučaja, tehnološki proces pripreme i proizvodnje sudžuka je izveden na način specifičan za dati proizvod. Dobijene vrednosti određene hemijskom analizom (vlaga, ukupan pepeo, natrijum hlorid, ukupne kiseline, masti, proteini i pH vrednost) u uzorcima domaćeg proizvedenog bosanskog sudžuka su bile statistički značajne ( $p<0.05)$. U uzorcima industrijski proizvedenog sudžuka za sadržaj vlage, ukupnog pepela, natrijum hlorida, ukupnih kiselina, proteina i pH vrednosti je ustanovljena statistički značajna razlika $(p<0.05)$, dok za sadržaj masti nije ustanovljena statistički značajna razlika između uzoraka ( $p>0.05)$. Rezultati instrumentalnog merenja boje su pokazali statistički značajne razlike $(p<0.05)$ za vrednosti parametra $a^{*}$ u uzorcima bosanskog sudžuka proizvedenog $u$ domaćinstvu i u industrijskim uslovima, te za vrednost parametra $L^{*}$ u uzorcima industrijski proizvedenog sudžuka. Nije utvrđena statistički značajna razlika $(p>0.05)$ za vrednost parametra $b^{*}$ u uzorcima bosanskog sudžuka proizvedenog u domaćinstvu i u industrijskim uslovima. U senzornoj evaluaciji je ustanovljena statistički značajna razlika $(p<0.05)$ za ukupnu ocenu za uzorke bosanskog sudžuka proizvedenog u domaćinstvu, dok za ukupnu ocenu industrijski proizvedenog sudžuka nije utvrđena statistička značajnost (p>0.05).

Ključne reči: bosanski sudžuk, tradicionalna i industrijska proizvodnja, hemijske i senzorne osobine.

Disclosure statement: No potential conflict of interest was reported by authors. 


\section{References}

Bozkurt, H. \& Bayrym, M. (2006). Colour and textural attributes of sucuk during ripening. Meat Science, 73, 344-350._doi: 10.1016/j.meatsci.2006.01.001.

Čengić, F., Smajić, A. \& Operta, S. (2008). Uticaj sirovinskog sastava i tehnološkog procesa na kvalitet kobasica. Radovi Poljoprivredno-prehrambenog fakulteta Univerziteta u Sarajevu, Vol. LIII, 59/1, 177-190.

Dučić, M., Vranić, D. \& Baltić, M. (2018). Selected physico-chemical properties of Serbian dry fermented sausages in different meat industries. Meat Technology 2, 120-126. DOI: https://doi.org/10.18485/meattech.2018.59.2.7

Ercoskun, H. \& Özkal, S. G. (2011). Kinetics of traditional Turkish sausage quality aspects during fermentation. Food Control, 22 (2) 165-172. doi:10.1016/j.foodcont.2010.06.015

Erkmen, O. \& Bozkurt, H. (2004). Quality Characteristics of Retailed Sucuk (Turkish Dry-Fermented Sausage). Food Technology and Biotechnology 42 (1), 63-69.

Ganić, A., Begić, M., Karahmet, E. \& Hamidović, S. (2018). Karakterizacija kvalitativnih parametara 'visočkog sudžuka" u cilju zaštite na nacionalnom nivou. XXIII. Savjetovanje o biotehnologiji, Čačak 9-10 mart 2018. Zbornik radova, 427-432.

Hromiš, N., Šojić, B., Škaljac, S., Lazić, V., Džinić, N., Šuput, D. \& Popović S. (2013). Effect of chitosan-caraway coating on color stability and lipid oxidation of traditional dry fermented sausage. Acta Periodica Technologica, 44, 57-65. DOI: 10.2298/APT1344057H

ISO - International Organization for Standardization (ISO). (1985). Sensory analysis. Method of quantitative descriptive analysis ISO 6564:1985. Geneva, Switzerland.

ISO - International Organization for Standardization (ISO). (1996). Meat and meat products. Determination of sodium chloride ISO 1841-1:1996. Geneva, Switzerland.

ISO - International Organization for Standardization (ISO). (2004). Meat and meat products. Measurement of pH ISO 2917:2004. Geneva, Switzerland.

ISO - International Organization for Standardization (ISO). (2007a). Meat and meat products. Determination of moisture BAS ISO 1442:2007. Geneva, Switzerland.

ISO - nternational Organization for Standardization (ISO). (2007b). Meat and meat products. Determination of nitrogen BAS ISO 937:2007. Geneva, Switzerland.
ISO - International Organization for Standardization (ISO). (2007c). Meat and meat products. Determination of total ash BAS ISO 936:2007. Geneva, Switzerland.

ISO - International Organization for Standardization (ISO). (2007d). Meat and meat products. Determination of total fat BAS ISO 1443:2007. Geneva, Switzerland.

Jahić, S. \& Pračić N. (2018). The influence of raw materials and different fermentation intervals on quality parameters of the traditionally produced bosnian sudžuk. Technologica Acta, 11 (1), 11-16.

Kurćubić, V., Mašković, P. \& Lilić, S. (2016). Senzorni i hemijski kvalitet sudžuka proizvedenog različitim tehnološkim postupcima. XXI. Savjetovanje o biotehnologiji, Zbornik radova, 21 (24), 679-684.

Operta, S., Smajić, A. \& Ganić A. (2007). Kvalitet bosanskog sudžuka proizvedenog u industrijskim uslovima. Radovi Poljoprivredno-prehrambenog fakulteta Univerziteta u Sarajevu, LII, 58/1, 239-247.

Operta, S., Dževdetbegović, M., Čorbo, S., Tahmaz, J. \& Šehović A. (2012). Fizičko-hemijska i senzorna svojstva bosanskog sudžuka proizvedenog u kontrolisanim uslovima od svežeg ohlađenog i zamrznutog goveđeg mesa. Tehnologija Mesa, 53 (2), 148-156.

Operta, S. (2018). Standardizacija bosanskog sudžuka proizvedenog u komori za zrenje. Radovi Poljoprivredno-prehrambenog fakulteta Univerziteta u Sarajevu, LXIII, 68/2, 155-167.

Ozkal, S. G. \& Ercoşkun, H. (2016). Kinetic Modeling of Quality Aspects of Fermented Sausage (Sucuk) During Storage. Kafkas Üniversitesi Veteriner Fakültesi Dergisi, 195-200. DOI:10.9775/kvfd.2016.16167

Official Gazette BiH. (2013). Pravilnik o usitnjenom mesu, poluproizvodima i proizvodima od mesa. Službeni Glasnik $\mathrm{BiH}, 83 / 2013$.

Siriken, B., Cadirci, O. \& Yenisey, C. (2009). Some microbiological and physico-chemical quality of Turkish sucuk (sausage). Journal of Animal and Veterinary Advances, (8) 10, 2027-2032.

Toldra, V. \& Reig, M. M. (2011). Innovations for healthier processed meats. Trends in Food Science and Technology, 22, 517-522. DOI:10.1016/J.TIFS.2011.08.007

Trajković, J., Mirić, M., Baras, J. \& Šiler, S. (1983). Analize životnih namirnica. Faculty of Technology and Metallurgy, University of Belgrade, Serbia.

Paper received: October $11^{\text {th }} 2021$.

Paper corrected: November $11^{\text {th }} 2021$.

Paper accepted: November $16^{\text {th }} 2021$. 